American Journal of Applied Sciences 4 (7): 484-490, 2007

ISSN 1546-9239

(C) 2007 Science Publications

\title{
Design and Performance of EPS Footing for Lightweight Farm Structure on Peat Soil
}

\author{
${ }^{1}$ Mohammad Abdullah, ${ }^{2}$ Bujang B.K. Huat, ${ }^{1}$ Rezuwan Kamaruddin, ${ }^{1}$ Abu Kasim Ali, \\ and ${ }^{2}$ Youventharan Duraisamy \\ ${ }^{1}$ Malaysian Agriculture Research Institute, Serdang, Selangor, Malaysia \\ ${ }^{2}$ University Putra Malaysia, Serdang, Selangor, Malaysia
}

\begin{abstract}
The objective of this research project was to find a potential replacement for the conventional pile foundation principally for peat soil. It is fundamentally meant for lightweight and impermanent agricultural farm structures. Preceding the design and development of the foundation the physical characteristics of the in-situ peat such as; peat depth, soil consolidation, soil compressibility, water table, liquid limit, soil moisture content, soil bulk density, loss on ignition, soil bearing capacity and soil shear strength were verified. Two types of foundation designs i.e. single shell and pad foundations were assessed. Both utilized Expanded Polystyrene (EPS) as the footing material. They were conceptually designed as floating foundation employing the weight compensation technique. The soil bearing capacity, soil shear strength, self-load and the lateral wind-load are factors taken into consideration in the footing design. The total design load was considered at $100 \mathrm{~kg}$ per foundation. The water table fluctuation, soil surface subsidence, the foundation vertical movement and its stability were constantly monitored. After a scheduled period, the foundations continue to stay intact.
\end{abstract}

Keywords: Peat soil, lightweight structures, foundations, pile footing, expanded polystyrene

\section{INTRODUCTION}

Peat land, covers more than 4 million $\mathrm{km}^{2}$ of the planet's surface. Representing $50-70 \%$ of the total wetlands on earth, it forms a sizeable component of land resources globally. Peat of the temperate countries is distinctively diverse from tropical peat, which is very woody in nature.

About 20 million hectares or $60 \%$ of the tropical peat is located in the South-East Asia countries. This is estimated to be roughly one tenth of the entire extent of the global peat land resource. Approximately $70 \%$ of the total peat land in South-East Asia is in Indonesia. Other major areas are located in Malaysia, with $2.6 \mathrm{x}$ $10^{6}$ hectares or $8 \%$ of its total land area; Thailand, Vietnam, Brunei Darussalam and the Philippines ${ }^{[1]}$ currently

The United Soil Classification System (USC) classified peat and muck as highly organic soils ${ }^{[2]}$. Generally soils containing more than $20 \%$ organic matters are termed organic soils but, the definition of peat differs between soil science and engineering definition. In soil science terminology, peat is a soil with organic content $>35 \%$. However, in engineering terminology peat is a soil with organic content $>75 \%{ }^{[3]}$.

The Department of Agriculture in peninsular Malaysia separates organic clay, muck and peat by the percentage Loss on Ignition (LOI). The criteria being; organic clay, muck and peat are soils with LOI $22-35$ $\%, 35-65 \%$ and $>65 \%$ respectively ${ }^{[4]}$.

Peat depth is another classification of peat, where soil with peat depth of $<1.0 \mathrm{~m}, 1.0-1.5 \mathrm{~m}, 1.5-3.0 \mathrm{~m}$, and $>3.0 \mathrm{~m}$ is classified as shallow, moderate, deep and very deep peat respectively ${ }^{[5]}$.

Peat soil is by nature complex and variable and its properties are difficult to classify with precision. Peat is a problematic soil with many adverse physical and mechanical properties such as: soil surface subsidence, high water-table, loose soil structure, and contain high volume of underground woody debris. The surface subsidence had been reported to occur at a substantial rate of about $10 \mathrm{~cm} / \mathrm{yr}$ in the first eight years after clearing $^{[6]}$.

Earlier studies conducted by $\mathrm{Ooi}^{[7]}$, Ismail ${ }^{[8]}$ and Andriesse $^{[9]}$ revealed that peat load bearing capacity was very low and was apparently influenced by the water table and the presence of subsurface woody debris. A recent study done by Mohammad and Ismail $^{[10]}$ indicated that the occurrence of solid underground woody debris could reach $15 \%$ of the soil volume. 
For those reasons, Tuncer ${ }^{[11]}$ suggested that all construction works on peat land should consider the fundamental geotechnical properties of the soil.

Today, various structures, roads and bridges have been built over peat soil. However, all these constructions almost definitely followed a standard practice for construction design on soft soil that is to consider piling works as a prerequisit. This was also suggested by Jarrett ${ }^{[12]}$.

Gan and $\operatorname{Tan}^{[13]}$ suggested that many construction methods had been practiced to overcome the problem of low load bearing capacity. Some common practices are; soil replacement, expediting pore-water dissipation and platform settlement through the insertion of prefabricated vertical drains and surcharge fills, installation of stone columns or sand compaction piles, embankment basal strengthening with geosynthetic materials, and usage of light weight materials to replace conventional fills. Another approach suggested by Biringen ${ }^{[14]}$ is to apply vertical loads for a specified period of time prior to placement of foundations or embankments. However, all these practices are constrained by technical feasibility, construction cost, space and time limitations, and preferences. Besides, they are more appropriate for bigger and heavier structures rather than the lightweight farm buildings.

Designs of buildings on peat should be projected towards lightweight structures without disregard of strength, durability and stability. Raft type foundations are commonly used on soils of low bearing capacity and varying compressibility ${ }^{[15]}$. While, Munzir ${ }^{[16]}$ proposed another posibility i.e. a shell foundation which is supposedly more economical and with bigger load bearing ability than a slab foundation.

The conventional concrete pile foundation for commercial scale netted structure is rather expensive, considering the average cost of building a $20 \mathrm{~m} \times 50 \mathrm{~m}$ netted structure to be about RM25,000 while the cost of the substructures i.e. the ground beam and the foundation is estimated between $10-20 \%$ of the total cost. Moreover it is not recyclable and it faces problems as the surface ground level subsides.

To resolve the problem a research project was proposed objectively to develop a new structural foundation as an alternative to the conventional design. Bearing in mind that it is especially for peat soil, the main characteristics to be considered and advantages that are being looked into are:
1. Stability - it is expected that this foundation shall remain stable and perform relatively as well for a long period of time.

2. Transportability and reusability- it is expected to be able to be moved to other sites when necessary and remain intact after several usage.

3. Ease of construction - it shall be easily molded into required shape especially for mass production, easily assembled and dismantled.

4. Environmentally compatible - its concept should be different from the pile foundation. It shall be based on floating or raft foundation where it will remain afloat whether the water table rises or falls. This is particularly important in peat area where the soil surface subsides unevenly.

5. Cost reduction - the cost shall be lower than the pile foundation which accommodate about $10 \%$ of the total cost of construction.

Knowing the problematic properties of peat soil, the material of construction will be a choice of light weight materials that could lessen the tendency for the structure to sink under its own weight. The material should also maintain the fundamental properties like; physical stability and durability, chemical inertness, formability and of course, it must be economically feasible.

Lightweight materials such as expanded polystyrene (EPS) which, basically can be produced in four common grades based on its density, as Standard Duty (SD), Heavy Duty (HD), Extra High Duty (EHD) and Ultra High Duty (UHD) according to the BS 3837 Part 1 (1986) could be looked into as a construction material for foundation footing. Studies on various materials used as fillers have proved that EPS has the advantage over others ${ }^{[17]}$ and its potential had been tested in its application to remedy settlement of bridge abutment in Malaysia since $1992^{[13]}$.

Expanded polystyrene was selected after considering the advantages it has to offer in comparison to other materials. To restrain the structure from sinking into the soft peat soil or being suspended above the soil surface when the soil subsides, the concept of floating or raft foundation was exploited, utilizing the weight compensation principle as the basis to determine the footing size.

The project was conducted at the Malaysian Agricultural Research and Development Institute (MARDI) at the Sessang Experimental Station in the state of Sarawak, Malaysia (Fig. 1). 




Fig. 1: Location of the research station.

\section{FIELD SITE AND SOIL PROPERTIES}

Field experiment was established on a $1 / 4$ ha plot of peat land (Fig. 2). Surrounding the experimental plot was secondary peat forest of the Anderson group with an average depth of more than four meters. Initial observation indicated that the water table in the vicinity fluctuated between $60 \mathrm{~cm}$ below to $10 \mathrm{~cm}$ above soil surface, depending on the seasons.

Verification of the soil properties was done prior to design and development of the foundations. Initially the peat depth was gauged. This was accomplished by driving a peat auger into the soil until it reached the clay pan. The measurement was done at thirteen locations throughout the plot.

Vane shear meter of different sizes i.e. $20 \mathrm{~mm} \times 40$ $\mathrm{mm}$ and $25.4 \mathrm{~mm} \times 50.8 \mathrm{~mm}$ were used to measure the soil shear strength from 24 locations. Measurements were taken at $0,25,50,75$, and $100 \mathrm{~cm}$ depths from each location.

Two cone penetrometers of different sizes i.e. cone size $3\left(3 \frac{1}{3} \mathrm{~cm}^{2}\right.$ base area) and cone size $4\left(5 \mathrm{~cm}^{2}\right.$ base area) were used to determine the cone index and bearing capacity of the soil. Similarly the measurements were taken from 24 locations at various depth ranges i.e. $0-25,25-50,50-75$, and 75-100 cm below soil surface.

Soil densities (bulk and dry density), specific gravity and consolidation tests on selected undisturbed samples were carried out. Table 1 summarizes the engineering properties of the Sessang peat.

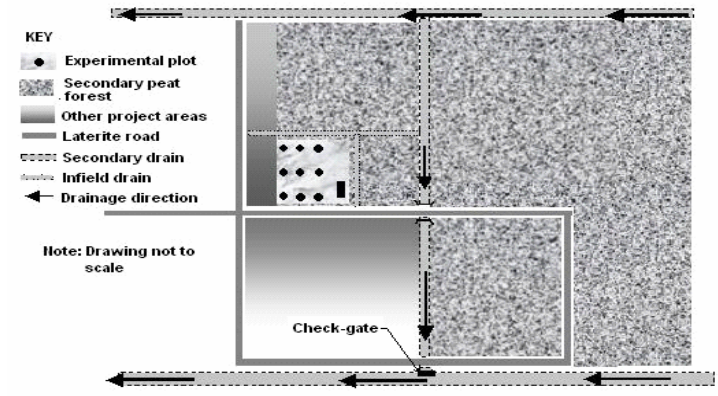

Fig. 2: The field site.

Table 1: Engineering Properties of the Sessang Peat.

\begin{tabular}{ll}
\hline Parameter & Value \\
\hline Liquid Limit & $213 \%$ \\
Water Content & $500 \%$ \\
Organic Content & $93 \%-98 \%$ \\
Fiber Content & $2 \%-7 \%$ \\
Bulk Density & $0.79-0.84 \mathrm{Mg} / \mathrm{m}^{3}$ \\
Dry Density & $0.15-0.23 \mathrm{Mg} / \mathrm{m}^{3}$ \\
Specific Gravity & $1.52-1.58$ \\
Vane Shear Strength & $9-17 \mathrm{kPa}$ \\
Bearing Capacity & $27-46 \mathrm{kPa}$ \\
Coefficient of & $0.12-7.69 \mathrm{~m} / \mathrm{MN}$ \\
Compressibility Volume & \\
Compression Index & $1.4-1.8$ \\
Coefficient of Consolidation & $0.0103 \mathrm{~cm} / \mathrm{min}$ \\
Coefficient of Secondary & 0.077 \\
Compression & \\
Ground Water Table & $0.10 \mathrm{~m} \mathrm{above} \mathrm{ground} \mathrm{-}$ \\
Soil pH & $0.6 \mathrm{~m} \mathrm{below}$ ground \\
& $4-5$ \\
\hline
\end{tabular}

The ground investigations revealed that the field site was covered by a blanket of peat soil of about $4 \mathrm{~m}$ thick, underlain by hard and stiff clay stratum. Based on the index tests carried out on the collected soil samples, the soils were found to be highly organic. This was also proven by visual observation done while sampling using the peat auger. The organic content was in the range of $93-98 \%$, and fiber content was between $2 \%$ to $7 \%$. Based on Von Post Scale, investigated soil falls under the amorphous/sapric peat (H7-H9), which is highly humified or decomposed soil. It was brown to brown black in color and had a strong smell. Laboratory bulk density shows that the unit weight of the peat soil is in the region of $0.79-0.84 \mathrm{Mg} / \mathrm{m}^{3}$. Dry density of the soil ranged from $0.15-0.23 \mathrm{Mg} / \mathrm{m}^{3}$, which is significantly lower than normal mineral soils. Consolidation tests carried out showed that the soil was highly compressible with compression index value in the range of $1.4-1.8$ and volume of compressibility 
0.12-7.69 $\mathrm{m}^{2} / \mathrm{MN}$. Whereas value of coefficient of consolidation $\left(c_{v}\right)$ is $0.0103 \mathrm{~cm}^{2} / \min \left(0.5418 \mathrm{~m}^{2} /\right.$ year $)$ and coefficient of secondary compression is 0.077 . The physical (engineering) properties of the Sessang peat fall within the range of other tropical peat soil ${ }^{[18]}$.

Figure 3 shows the vane strength plot. The measured shear strength for the peat ranged from $9-16$ $\mathrm{kPa}$, which is generally lower than shear strength of soft clays. The bearing capacity of the soil, based on the cone penetrometer test (Table 1) was found to range from $27-46 \mathrm{kPa}$. Due to its low shear strength this soil as expected would have low bearing capacity, and hence would not be able to support much foundation loading.

Eight observation wells and twelve subsidence poles were installed within the experimental plot. Infield drains were constructed to drain off flooding water. Ground water level measurement made in the observation wells showed that the ground water level was close to the ground level during wet season and subside to $0.6 \mathrm{~m}$ below ground level during dry season (Fig. 4). Therefore the ground water levels were subjected to seasonal fluctuations and the drainage conditions in the vicinity.

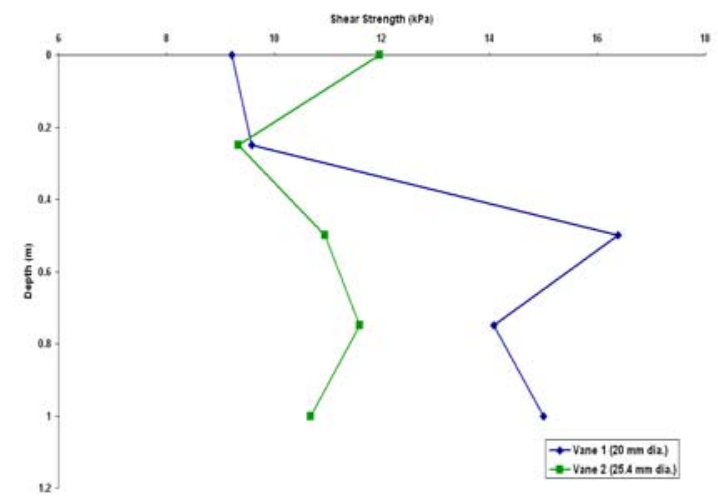

Fig. 3: Vane shear strength.

Figure 5 shows the soil surface subsidence, monitored over the project duration of nearly 1 year. The station received intense rainfalls in the first half and lesser in the next half of the study period. It is noticeable that there is increase in elevation of soil surface or heave in the first half of the study period as indicated by lines representing the twelve subsidence poles. However, the next half of the period saw the soil surface moved down between $5-40 \mathrm{~mm}$ below the original level. This is supported by Figure 5, which indicated high water table in the same period.

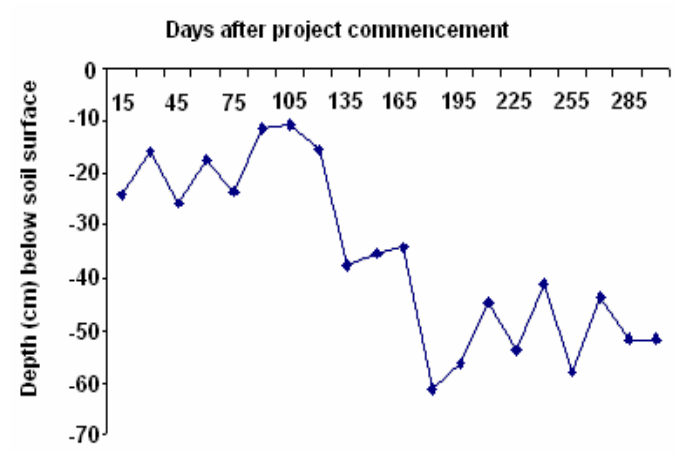

Fig. 4: Water level variations.

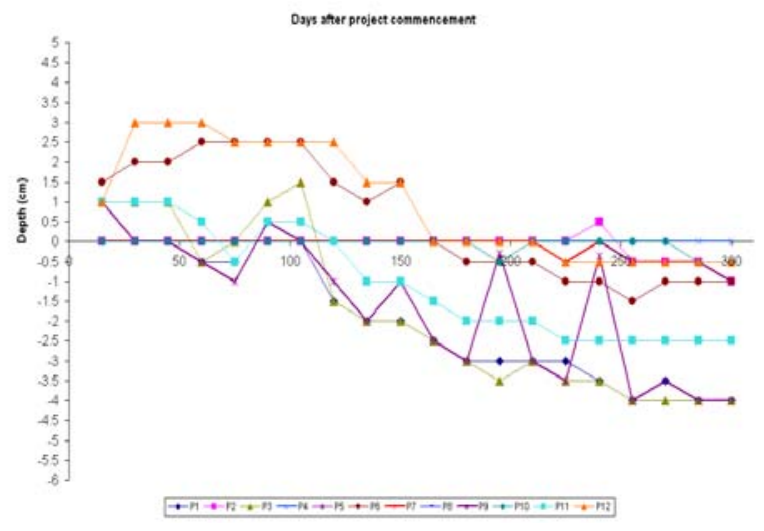

Fig. 5: Soil surface subsidence.

\section{FOUNDATION DESIGN AND EXPERIMENTAL PROCEDURES}

The foundations were designed as a floating type or raft foundation by applying Weight Compensation principle. Theoretically it will keep the foundation afloat as the total load exerted by the foundation on its environs, equals the weight of the soil displaced. The total load, which is contributed by the footing and structure self-weights, the lateral wind load and a safety factor, is subsequently translated into volume of soil to be removed. Thus, the footing size is tailored according to the volume of soil to be removed.

Two types of footing were tested i.e. shell and pad footings (Fig. 6). The size of the footings was determined based on the design load of $100 \mathrm{~kg}$. The shell footing is basically two portions of EPS block affixed together using metal plates. The top Portion A is a solid block measuring $65 \times 65 \times 25 \mathrm{~cm}$ while the bottom Portion $\mathrm{B}$ is another block of size $65 \times 65 \times$ 
$12.5 \mathrm{~cm}$ with its central portion measuring $45 \times 45 \times$ $12.5 \mathrm{~cm}$ cut off to form a hollow section.

Expanded Polystyrene (EPS) of standard quality or standard duty (SD) with a density of $15 \mathrm{~kg} \mathrm{~m}^{-3}$ were used. The properties of the SD EPS are shown in Table 2.

Three treatments were imposed; T1, T2, and T3, where, $\mathrm{T} 1$ is a pad foundation without geotextile lining; $\mathrm{T} 2$ is pad foundation with geotextile lining, and T3 is the shell foundation. Each footing (T1, T2 and T3) was replicated 3 times (R1, R2 and R3)

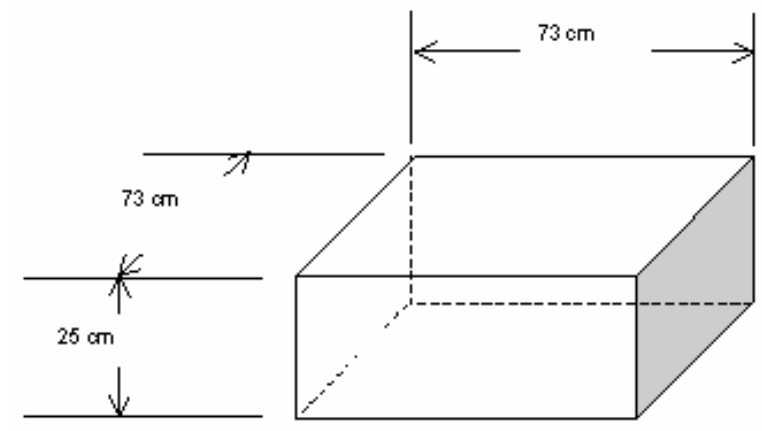

(a) Pad footing.

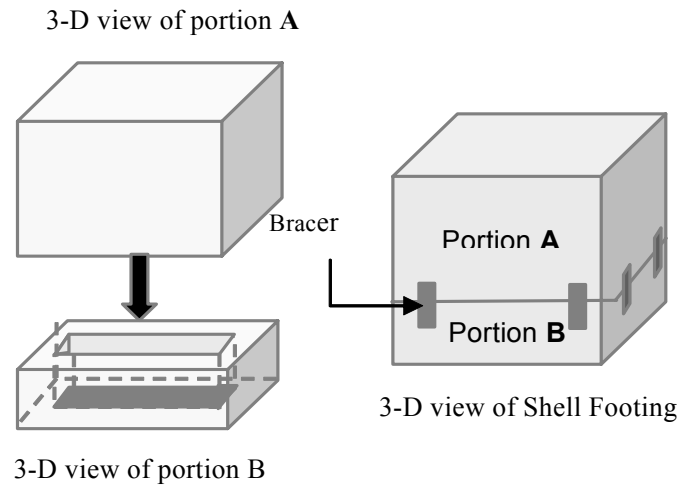

(b) Shell footing

Fig. 6: Experimental footing.

Table 2: Properties of Standard Duty polystyrene.

\begin{tabular}{|c|c|c|c|}
\hline Physical Properties & Testing Std. & Unit & Test Result \\
\hline Min. apparent density & DIN 53420 & $\mathrm{Kg} \mathrm{m}^{-3}$ & 15 \\
\hline $\begin{array}{l}\text { Construction material } \\
\text { class }\end{array}$ & DIN 4102 & & $\begin{array}{l}\text { B1, Flame } \\
\text { resistant }\end{array}$ \\
\hline Thermal conductivity & DIN 52612 & & \\
\hline $\begin{array}{l}\text { Measured value at } \\
+10^{\circ} \mathrm{C}\end{array}$ & & $\mathrm{mW} /(\mathrm{m} \cdot \mathrm{K})$ & $36-38$ \\
\hline $\begin{array}{l}\text { Design value as } \\
\text { specified in DIN } 4108\end{array}$ & & $\mathrm{~mW} /(\mathrm{m} \cdot \mathrm{K})$ & 40 \\
\hline Compressive & DIN 53421 & $\mathrm{kPa}$ & $60-110$ \\
\hline
\end{tabular}

\begin{tabular}{|c|c|c|c|}
\hline $\begin{array}{l}\text { under } \\
\text { compression }\end{array}$ & & & \\
\hline $\begin{array}{lr}\text { Long } & \text { term } \\
\text { compressive stress } \\
<2 \% \text { compression }\end{array}$ & & $\mathrm{kPa}$ & $15-25$ \\
\hline Flexural strength & DIN 53423 & $\mathrm{kPa}$ & $60-300$ \\
\hline Shear strength & DIN 53427 & $\mathrm{kPa}$ & $80-130$ \\
\hline Tensile strength & DIN 53430 & $\mathrm{kPa}$ & $110-290$ \\
\hline $\begin{array}{l}\text { Modulus of elasticity } \\
\text { (compressive test) }\end{array}$ & DIN 53457 & $\mathrm{MPa}$ & $1.6-5.2$ \\
\hline $\begin{array}{l}\text { Heat distortion } \\
\text { temperature - Short- } \\
\text { term }\end{array}$ & DIN 53424 & ${ }^{\circ} \mathrm{C}$ & 100 \\
\hline $\begin{array}{l}\text { Long-term at } 20,000 \\
\mathrm{Nm}^{-2}\end{array}$ & DIN 18164 & ${ }^{\circ} \mathrm{C}$ & 75 \\
\hline Specific heat capacity & DIN 53765 & $\mathrm{~J} /(\mathrm{kg} . \mathrm{K})$ & 1210 \\
\hline \begin{tabular}{lrr} 
Water & \multicolumn{2}{c}{ absorption } \\
when & kept & under \\
water & (percent & by \\
volume) & After & 7 \\
days & &
\end{tabular} & DIN 53434 & $\%$ & $0.5-1.5$ \\
\hline After 28 days & & $\%$ & $1.0-3.0$ \\
\hline
\end{tabular}

\begin{tabular}{|c|c|}
\hline $\begin{array}{l}\text { Resistances } \\
\text { chemicals }\end{array}$ & \\
\hline Active agent & Styropor P, F (FH) \\
\hline $\begin{array}{l}\text { Salt } \\
\text { (seawater) }\end{array}$ & + \\
\hline $\begin{array}{l}\text { Soap and wetting } \\
\text { agent solution }\end{array}$ & + \\
\hline $\begin{array}{l}\text { Bleaching solutions such as } \\
\text { hypochlorite, chlorine } \\
\text { hydrogen peroxide solutions }\end{array}$ & + \\
\hline Dilute acid & + \\
\hline $\begin{array}{l}35 \% \text { hydrochloric } \\
\text { acid, up to } 50 \% \text { nitric } \\
\text { acid }\end{array}$ & + \\
\hline $\begin{array}{l}\text { Anhydrous acids e.g. fuming sulfuric } \\
\text { acid, glacial acetic acid, } 100 \% \text { formic } \\
\text { acid }\end{array}$ & - \\
\hline $\begin{array}{l}\text { Sodium hydroxide, potassium } \\
\text { hydroxide, ammonia solution }\end{array}$ & + \\
\hline $\begin{array}{l}\text { Organic solvents e.g. acetana, ethyl } \\
\text { acetate, benzene, xylene, paint } \\
\text { thinner, trichloroethylene }\end{array}$ & - \\
\hline $\begin{array}{l}\text { Saturated aliphatic hydrocarbons, } \\
\text { surgical spirit, test benzene }\end{array}$ & $-(+-)$ \\
\hline Paraffin oil, vaseline & $+-(+)$ \\
\hline Diesel oil & $-(+)$ \\
\hline $\begin{array}{l}\text { Motor fuel (normal } \\
\text { and super gasoline) }\end{array}$ & - \\
\hline $\begin{array}{ll}\text { Alcohols } & \text { e.g. } \\
\text { methanol } & \text { and } \\
\text { methanol } & \end{array}$ & +- \\
\hline Silicone oil & + \\
\hline $\begin{array}{l}\text { Resistant: The foamed plastic is not destroyed even af } \\
\text { - Conditional resistant: The foamed plastic may shr } \\
\text { rolong exposure } \\
\text { Unresistant: The foamed plastic shrinks at lesser or gr } \\
\text { Source: Technical Literature. BASF - CMS Modular H }\end{array}$ & $\begin{array}{l}\mathrm{r} \text { long exposure } \\
\mathrm{k} \text { or suffer attack to the surface after } \\
\text { ter rate or is dissolved } \\
\text { using Sdn. Bhd. Kuching, Sarawak): }\end{array}$ \\
\hline
\end{tabular}


severe and extricate underground woody debris and soil from the pit. Subsequently, clean soil was refilled into the pit. The added soil was constantly compacted and checked with cone penetrometer to ensure its load bearing capacity is comparable to the original. The pit was refilled until its level was about $0.35 \mathrm{~m}$ and $0.50 \mathrm{~m}$ below the soil surface for pad and shell footing respectively (Fig. 7).

In the case of $\mathrm{T} 1$ and $\mathrm{T} 3$, the EPS footing with a column intact was placed in the pit directly on the soil surface. Whereas in T2, a layer of geotextile lining was placed on the soil surface within the pit and a layer of sand, about 30-50 mm thick was spread on top of the geotextile lining before placement of the footing on it. The idea was to give a firmer base for the footing to rest. The pits were then completely covered with peat soil and compacted.

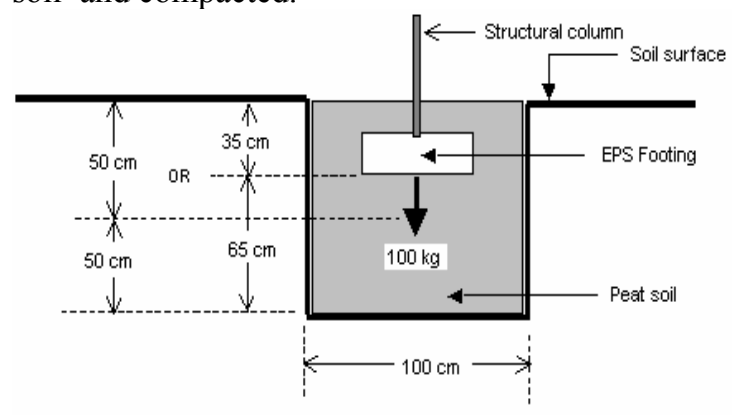

Fig. 7: Position of foundation beneath soil surface.

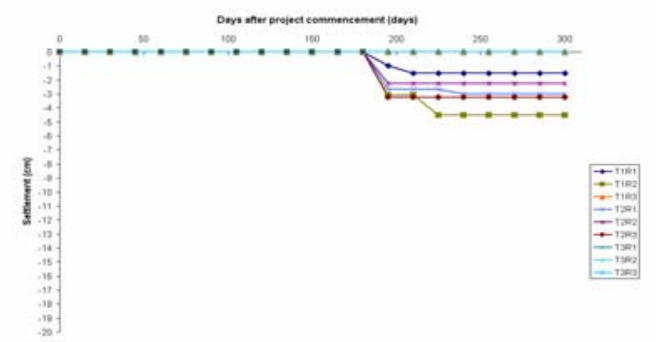

Fig. 8: Foundation movements.

\section{PERFORMANCES OF THE FOOTINGS}

The footings were monitored in term of vertical movements (settlement or heave). The outcome of nine month monitoring is presented in Figure 8. It should be noted that T1R1, T1R2, T2R1, T2R2 and T2R3 were the earlier batch to be completed. Whereas, footings T1R3, T3R1, T3R2 and T3R3 were completed only six months later. The figure shows that settlement in the earlier batch ranged only from zero (no settlement) to $45 \mathrm{~mm}$ after a period of 210 days, and appeared to come to rest thereafter. This is consistent with the general surrounding ground movements as shown in
Figure 5 above. For the later batch, there was no indication of any settlement after 4 months of their installation. This could be related to relatively the drier months when the monitoring was done. There also appear to be no significant different in the settlement performance of footings without or with the geotextile and sand padding ( $\mathrm{T} 1$ and $\mathrm{T} 2$ respectively), as well as when compared to the shell footing (T3). In term of material durability, there appears to be no damage or deterioration to the EPS footings though they had been left for nearly 1 year.

\section{CONCLUSION}

This study has shown that footing made from EPS using the weight compensation technique is a viable option for lightweight farm structures.

The output of this project is expected to reduce the cost of farm structures since the cost of polystyrene and other material of construction are cheaper than the conventional materials. This will make high value crops production under netted structures or rain shelter more competitive. A further advantage of the proposed foundations is that can be reused and transportable.

Thus, it can be expected to have a demand and potential market amongst farmers, commercial agricultural producers and manufactures of building materials.

\section{REFERENCES}

1. Anon. Peatlands by Region. http://www.peat_portal.net/

2. Singh, H., Bahia, H.M and Huat, B.B.K. 1997. Varying Perspectives on Peat, Its Occurence In Sarawak and some Geotechnical Properties. Proc. on Conf. on Recent Advances In Soft Soil Engineering. Kuching Sarawak Mar 5-7, 1997. $1: 135-149$.

3. Huat, B.B.K., Shukri, M. and Thamer, A.M. 2005. Effect of Chemical Admixtures on the Engineering Properties of Tropical Peat Soil. American Journal of Applied Sciences Science Publication N.Y. USA. 2(7): 113-1120, 2005.

4. Ambak, K., Aziz, B., Ting, C.C and Abdul Wahab, N. 1995. Improvement of Problem Soils In Malaysia for Sustainable Agriculture. Proc. Int. Conf. Soil Resources and Sustainable Agriculture, Kuala Lumpur, Malaysia, 1995. 271-286.

5. Abdul Jamil, M.A., Chow, W.T., Chan, Y.K. and Yew, S.K. 1989. Landuse of Peat in Peninsular Malaysia. Proc. Nat. Workshop on Peat Research And Development, MARDI, 27-39, 
6. Anon ${ }^{2}$ 1991. Characterisation, distribution and utilisation of peat in Malaysia. Proceedings of the International Symposium on Tropical Peat, 1991.

7. Ooi, H.S. (1982). Agricultural Engineering Notes. MARDI, Serdang, 1982

8. Ismail, A.B. 1984. Characterisation of Lowland Organic Soils in Peninsular Malaysia. Proc. Workshop on Classification and Management of Peat In Malaysia. Ed. Pushparajah. Malaysian Soil Sc. Society, 1984.

9. Andriesse, P. 1988. Nature And Management of Tropical Peat Soil. FAO Soils Bulletin 59: FAO, United Nations, Rome, 1988.

10. Mohammad, A. and Ismail, A.B. 2005. Quantification of Woody Biomass after Clearing of Peat Forest. J. Trop. Agric. \& Food Sci, (MARDI) 33(2): 293-302

11. Tuncer, B.E. 1997. Constructioon Over Peat and Organic Soils. Proc. on Conf. on Recent Advances in Soft Soil Engineering, Kuching Sarawak Mar 57, 1997. 1:85-108.

12. Jarrett, P.M. 1997. Recent Development in Design and Construction on Peats and Organic Soils. Proc. on Conf. on Recent Advances In Soft Soil Engineering Kuching Sarawak Mar 5-7, 1997. 1: 116.

13. Gan, C.H. and Tan, S.M. 2003. Some Construction Experiences on Soft Soil using Light Weight Materials. Proc. of the $2^{\text {nd. }}$ Int. Conf. on Advances in Soft Soil Engineering and Technology, 2-4 July, 2003 Putrajaya, M'sia.: 609-616
14. Biringen, E. 2003. Improvement of Soft Ground by Radial Preloading. Proc. of The $2^{\text {nd. Int. Conf. on }}$ Advances in Soft Soil Engineering and Technology, 2-4 July, 2003 Putrajaya, M'sia.: 741752

15. McManus, K., Sukkar, F. And Hassan, R. 1997. Construction Technology of Supporting Light Structures on Sarawak's Soft Soils - Malaysia. Proc. on Conf. on Recent Advances in Soft Soil Engineering, Ed. Huat, B.B.K \& Bahia, H.M. Kuching, Sarawak, Mar 5-7, 1997. 1: 425-439.

16. Munsir, H.A., Huat, B.B.K. and Noorzaei, J. 2003. Potential Usage of Shell Foundations on Soft Ground. Proc. of the $2^{\text {nd. }}$ Int. Conf. on Advances in Soft Soil Engineering and Technology, 2-4 July, 2003, Putrajaya, M'sia.: 573-579

17. Frydenlund, T.E. and Aaboe. R. 1997. Expanded Polystyrene - The Light Solution. Proc. on Conf. on Recent Advances in Soft Soil Engineering Vol.I. Kuching Sarawak Mar 5-7, 1997: 309-324.

18. Huat, B.B.K. 2004. Organic and Peat Soils Engineering. UPM Press. Serdang 2: 70 